\title{
Does resilience influence food waste causes? A systematic literature review
}

\section{A resiliência influencia as causas de desperdício de alimentos? Uma revisão sistemática de literatura}

\author{
Camila Colombo de Moraes ${ }^{1}$ (D) \\ Flávio Henrique De Oliveira Costa ${ }^{1}$ (D) \\ Andrea Lago da Silva ${ }^{1}$ (D) \\ Ivete Delai ${ }^{1}$ (i) \\ Carla Roberta Pereira²
}

\section{GESTÃO PRODUÇÃO}

ISSN 0104-530X (Print) ISSN 1806-9649 (Online)

\begin{abstract}
How to cite: Moraes, C. C., Costa, F. H. O., Silva, A. L., Delai, I., \& Pereira, C. R. (2019). Does resilience influence food waste causes? A systematic literature review. Gestão \& Produção, $26(3)$, e4474. https://doi.org/10.1590/0104-530X4474-19
\end{abstract}

\begin{abstract}
Studies that seek to relate resilience and food waste are still at an early stage. For organizations to be prepared to avoid and/or reduce it to improve their operations it is necessary to understand the impact of resilience on the food waste reduction. The aim of this article is to identify how elements of resilience can influence the causes of food waste in retail. To that end, we conducted a systematic literature review, which resulted in 90 articles. Next, we conducted a content analysis to facilitate a rigorous exploration of complex issues in the management field, seeking to relate the elements of resilience to the causes of food waste. We imported the articles into the QDA Miner qualitative data analysis software and then separated phrases and texts following the codebook guidelines. It was possible to locate common properties to the articles and to make initial comparisons between the resilience and food waste causes. As a result, it was observed that the elements of resilience can positively or negatively influence the causes of food waste in the retail and that most of these elements are related to the anticipation. The main elements of resilience identified are: Flexibility, Visibility and Collaboration. However, this influence is partial, since some of the elements, such as Redundancy and Financial Strength, prevent the full implementation of waste reduction. Finally, we discuss the study's limitations and opportunities for further development in the conclusion.
\end{abstract}

Keywords: Food waste; Elements; Resilience; Retail.

Resumo: Estudos que buscam relacionar a resiliência e o desperdicio de alimentos encontram-se ainda em fase exploratória e de desenvolvimento. Observa-se, portanto, a necessidade de compreender como a resiliência pode influenciar a redução do desperdício de alimentos, de forma que as organizações estejam preparadas para evitá-lo elou reduzi-lo e, consequentemente, obter melhorias em suas operações. O objetivo desse artigo é identificar como os elementos de resiliência podem influenciar as causas do desperdicio de alimentos no varejo. Para tanto, realizou-se uma revisão sistemática de literatura que resultou em 90 artigos. A análise de conteúdo foi utilizada para facilitar a exploração rigorosa de questões complexas no campo de gestão, procurando relacionar os elementos de resiliência com as causas do desperdicio de alimentos. Os artigos foram inseridos no software QDA Miner de análise qualitativa e passaram por uma separação de frases e textos de acordo com um codebook, sendo possível localizar propriedades comuns aos artigos e elaborar comparações iniciais entre resiliência e causas de desperdicio de alimentos. Assim, observou-se que elementos de resiliência podem influenciar positiva ou negativamente as causas de desperdício de alimentos no varejo e que, a maior parte desses elementos são relacionados à antecipação. Os principais elementos de resiliência identificados são: Flexibilidade, Visibilidade e Colaboração. Contudo, essa influência é parcial, visto que alguns dos elementos, como a Redundância e Saúde Financeira, impedem que a redução do desperdicio seja de fato implementada. Limitações e oportunidades para estudos futuros foram ainda destacados na conclusão.

Palavras-chave: Desperdicio de alimentos; Elementos; Resiliência; Varejo.

${ }^{1}$ Programa de Pós-graduação em Produção, Departamento de Engenharia de Produção, Universidade Federal de São Carlos - UFSCar, Rodovia Washington Luís, Km 235, CP 676, CEP 13560-970, São Carlos, SP, Brasil, e-mail: camila.cmoraes@hotmail.com; flaviocosta91@hotmail.com; deialago@ufscar.br; ivete@dep.ufscar.br

${ }^{2}$ Departamento de Engenharia de Produção e Sistemas, Universidade do Estado de Santa Catarina - UDESC, Campus Universitário Prof. Avelino Marcante, Rua Paulo Malschitzki, 200, Zona Industrial Norte, CEP 89219-710, Joinville, SC, Brasil, e-mail: carla. pereira@udesc.br

Received Nov. 22, 2017 - Accepted May 17, 2018

Financial support: São Paulo Research Foundation (FAPESP), Grant \#2017/00763-5. Coordination for Improvement of Personnel and Higher Education (CAPES), Financing Code 001. National Council for Scientific and Technological Development (CNPq), code $305819 / 2016-0$. 


\section{Introduction}

The growing demand for natural resources, driven by population growth, is seen as a threat to sustainable development. Food waste is a challenge because food, as being a basic human need, requires an intense exploitation of natural resources (Beretta et al., 2013; Gustavsson et al., 2011; Parfitt et al., 2010). Thus, reducing food waste may be part of the solution to ensure supply (Derqui et al., 2016). In addition to the depletion of natural resources, food waste has a major impact on the environment, contributing to greenhouse gas emissions in landfills and also during activities associated with production, processing, manufacturing, transportation, storage, distribution and retail (Göbel et al., 2015; Papargyropoulou et al., 2014; Thyberg \& Tonjes, 2016). Regarding the social perspective, it is considered an ethical and moral dimension within the concept of global food security, since food production should meet the needs of a growing population (Tostivint et al., 2017). As for the economic impacts, these stem from the costs of food waste and their effects on the chains (Papargyropoulou et al., 2014).

Although the waste occurs at all levels of the chain, retail has a significant impact, since food has gone through most value-adding activities, accumulating costs and natural resources (Mena et al., 2011). Lebersorger \& Schneider (2014) pointed out that, although retail food waste has already been addressed, reliable data in the sector are still scarce, causing economic, environmental and social costs to have a negative impact on its image. Moreover, food retailing has great market power: it can influence decisions across the chain and disseminate innovations and information, acting as coordinator and/or inducer of changes. In order to meet the world's growing food needs, it is important not only to increase food production, but also to mitigate the causes of waste (Halloran et al., 2014).

Fahimnia \& Jabbarzadeh (2016) and FAO (2016) stated that resilience between the links in the chain becomes a necessary element to simultaneously sustain economic growth, improve social and environmental impacts while being adaptive to disturbances and external pressures. Resilience is defined as the adaptive capacity of a supply chain to withstand and cope with unexpected events (ruptures), maintaining control over its structure and functions, and enabling recovery and response to such disruptions, in order to restore the chain to the original (or better) conditions of operations (Christopher \& Peck, 2004; Kamalahmadi \& Parast, 2016). Reducing food waste can be translated into new business opportunities, reduced operating costs, and decreased environmental and social impacts (Manning \& Soon, 2016). Food retailing in particular has incorporated sustainability issues into its mission due to the growing importance of this concept to consumers and other stakeholders.

In the research carried out, we have observed the existence of studies that address important elements of resilience (Ali et al., 2017; Kamalahmadi \& Parast, 2016; Scholten et al., 2014) or the reduction of food waste (Balaji \& Arshinder, 2016) separately, but discussions on the integration of these themes are still at an early stage (Macfadyen et al., 2015; Manning \& Soon, 2016). It is therefore necessary to evaluate how resilience can influence food waste reduction so that organizations can be prepared to avoid and/or reduce waste and to obtain improvements in their operations. As a first step in exploring this relationship, a systematic literature review sought to correlate these two constructs, since no studies were found to do this research.

The purpose of this article is to identify the relationship between the elements of resilience and the causes of food waste in retail. The article is divided into five sections. The first contextualizes the problem to be explored and the objective. The second presents the methodological procedures for the systematic literature review. The third and fourth conceptualize the two major themes under study: resilience and waste reduction. The fifth discusses and analyzes the influence of resilience elements on the causes of waste reduction. The last section presents conclusions and limitations of this study as well as suggestions for future work.

\section{Methodological procedures}

The study began with a scope review, which sought to define the research problem, refine objectives and select keywords to build search strings (Badger et al., 2010; Jesson et al., 2011). Next, we developed review issues (Table 1) and a systematic review search protocol to define all steps and requirements to be followed, such as the databases for this research: Scopus, Web of Science (Buchinger et al. al., 2014) and Scielo (to capture Brazilian'studies about the subject under study). Search strings were built based on constructs and keywords (including synonyms and related words), considering articles published in the last 17 years (2000 to 2017), insofar as publications about resilience in supply chains began in early 2000 (Ali et al., 2017), those about food waste had the first step in 2008 (Alexander \& Smaje, 2008). Also, no time constraint was placed for this construct, in order to obtain a greater number of articles.

The filters used for the selection were: 1 ) reading of the title, abstract and keywords; 2) reading of the introduction and conclusion; 3 ) analysis of the quality of the journal, complete reading and evaluation of the quality of the article (critical reading).

We sought to select articles that most helped to answer the proposed revision questions, and also 
Table 1. Systematic Review Protocol.

\begin{tabular}{|c|c|c|}
\hline Review Questions & Constructs & Strings \\
\hline $\begin{array}{l}\text { 1. What elements create resilience } \\
\text { in the supply chain? }\end{array}$ & Supply chain resiliency & $\begin{array}{l}\text { ((“supply chain*”) w/3 (resilien* OR } \\
\text { risk* OR vulnerabilit*)) }\end{array}$ \\
\hline $\begin{array}{l}\text { 2. What causes food waste in the } \\
\text { supply chain? }\end{array}$ & $\begin{array}{l}\text { Food waste management / } \\
\text { reduction }\end{array}$ & $\begin{array}{l}\text { ((“supply chain*”) AND ((food) W/5 } \\
\text { (wast* OR surplus OR los*)) AND (cause* } \\
\text { OR source* OR origin* OR minimi* OR } \\
\text { prevent* OR generat* OR reduct* OR } \\
\text { manage* OR practice* OR strateg*)) }\end{array}$ \\
\hline $\begin{array}{l}\text { 3. How do elements of resilience } \\
\text { influence the causes of food waste? }\end{array}$ & $\begin{array}{l}\text { Resilience in the supply } \\
\text { chain } \\
\text { Food waste management }\end{array}$ & $\begin{array}{l}\text { ((“supply chain*”) w/3 (resilien* OR risk* } \\
\text { OR vulnerabilit*)) AND ((food) AND (wast* } \\
\text { OR surplus OR los*)) }\end{array}$ \\
\hline
\end{tabular}

Source: authors.

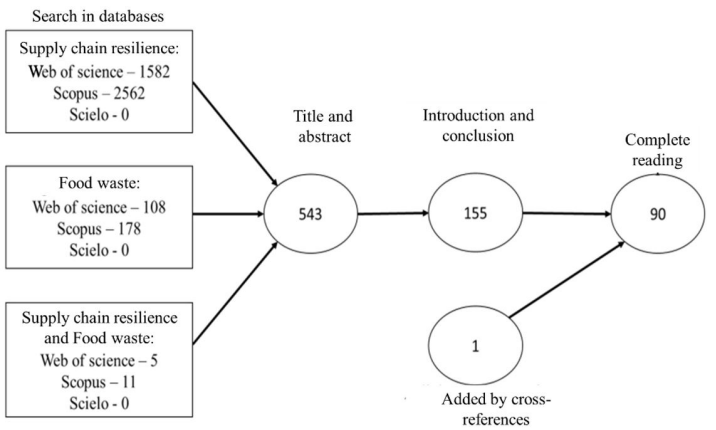

Figure 1. Systematic review procedures. Source: authors.

considered cross references during the critical reading of the articles (Hohenstein et al., 2015; Ali et al., 2017). After the conclusion of the systematic review, the main references in the study topic, which were not located in the searches, were added (Denyer \& Tranfield, 2009). Figure 1 shows the filters considered, as well as the number of resulting articles.

The selected articles were read and imported into the QDA Miner software for content analysis, following recommendations by Bardin (2008) and Krippendorff (2013). After a more detailed reading, codes were created for each identified element of resilience and cause of wasted food. As the objective of this study was to identify the impact of resilience on the causes of food waste, and as these elements are already defined in the literature, the analysis of the causes and of the influence of the elements on it was carried out in articles related to food waste; that is, in the articles resulting from strings 2 and 3 , totaling 34 articles. The relationships between these constructs were identified through the co-occurrence or the overlap of the QDA Miner proximity coding (Provalis Research, 2017).

\section{Causes of food waste}

Although the terms food loss and food waste are used interchangeably, "food loss" is located in the early stages of the chain, such as in production, post-harvest and processing (Parfitt et al., 2010; Thyberg \& Tonjes, 2016) and is related to the unintentional reduction of food available for consumption (FAO, 2013), a result of chain inefficiencies and climatic issues (Gustavsson et al., 2011). "Food waste" refers to the intentional disposal of food items (FAO, 2013), occurring in the final stages of the chain, during distribution, sale and consumption - the latter linked specifically to consumer behavior (Parfitt et al., 2010; Thyberg \& Tonjes, 2016). In this article, food losses and wastage are treated as synonyms and refer to the loss of edible food material, so term "food waste" will be used for standardization throughout the text.

Food waste is produced due to various causes and at different processing stages, from production to consumption. In developing countries, such as Brazil, it is mainly caused by managerial, financial and technical constraints related to harvesting and storage techniques, refrigeration facilities with poor temperature control, infrastructure, packaging and commercialization (Cicatiello et al., 2016). The main causes of food waste identified are presented in Table 2. It is important to note that in the case of this article, the causes presented refer only to those related to retail, not including those portrayed in the articles referring to primary production, post-harvesting, processing, distribution and consumption.

To better identify and group the causes, we used the model created by Bilska et al. (2016), which groups the causes of waste based on the Ishikawa diagram. Although this model is used to analyze the causes of food retail waste, it does an adaptation of the original Ishikawa diagram, for example, by withdrawing the analysis of the environment. For use in this study, it was deemed necessary to use the original form of the diagram, keeping all groups, but with the retail food focus in each of the six analyzes that can be done using the diagram. Although it was developed for the industrial context, the Ishikawa diagram proved to be a suitable tool for the proposed analysis. 
Table 2. Main causes of food waste in retail.

\begin{tabular}{|c|c|c|c|}
\hline $\begin{array}{l}\text { Group of } \\
\text { causes }\end{array}$ & Food waste causes & Definition & Authors \\
\hline \multirow[t]{5}{*}{$\begin{array}{l}\text { Machines } \\
\text { (equipment) }\end{array}$} & Cold chain breaking & $\begin{array}{l}\text { Problems in the cold chain, lack } \\
\text { structure and equipment to maintain } \\
\text { proper food temperature and for a } \\
\text { longer period of time. }\end{array}$ & $\begin{array}{l}\text { Girotto et al. (2015), } \\
\text { Mena et al. (2014), Priefer et al. } \\
\text { (2016) }\end{array}$ \\
\hline & $\begin{array}{l}\text { Problems with transport } \\
\text { equipment }\end{array}$ & $\begin{array}{l}\text { Damage to products due to } \\
\text { malfunction, absence, breakage or } \\
\text { inefficiency of transport equipment. }\end{array}$ & $\begin{array}{l}\text { Beretta et al. (2013), } \\
\text { Cicatiello et al. (2016), } \\
\text { Garrone et al. (2014), } \\
\text { Mena et al. (2011) }\end{array}$ \\
\hline & Display problems & $\begin{array}{l}\text { Inadequate exposure and / or } \\
\text { insufficient space for shelf storage. }\end{array}$ & $\begin{array}{l}\text { Girotto et al. (2015), Thyberg } \\
\text { \& Tonjes (2016) }\end{array}$ \\
\hline & $\begin{array}{l}\text { Lack of refrigerated } \\
\text { transport }\end{array}$ & $\begin{array}{l}\text { Failure or inefficiency of the vehicle/ } \\
\text { truck. }\end{array}$ & $\begin{array}{l}\text { Balaji \& Arshinder (2016), } \\
\text { Bilska et al. (2016), Mena et al. } \\
\text { (2014), Raak et al. (2017) }\end{array}$ \\
\hline & Storage problems & $\begin{array}{l}\text { Failure, inefficiency, or lack of storage } \\
\text { equipment. }\end{array}$ & $\begin{array}{l}\text { Bilska et al. (2016), } \\
\text { Canali et al. (2017) }\end{array}$ \\
\hline \multirow[t]{10}{*}{$\begin{array}{l}\text { Method } \\
\text { (procedure) }\end{array}$} & Inadequate storage & $\begin{array}{l}\text { Poor storage in the gondola, in the } \\
\text { transportation, in the logistics center. }\end{array}$ & $\begin{array}{l}\text { Balaji \& Arshinder (2016), } \\
\text { Tromp et al. (2016) }\end{array}$ \\
\hline & Rigid quality standards & $\begin{array}{l}\text { Norms imposed with exacting } \\
\text { cosmetic standards to accept food }\end{array}$ & $\begin{array}{l}\text { Göbel et al. (2015), Richter \& } \\
\text { Bokelmann (2016), Thyberg } \\
\text { \& Tonjes (2016), Mena et al. } \\
\text { (2011) }\end{array}$ \\
\hline & $\begin{array}{l}\text { Lack of definition of } \\
\text { responsibility at work }\end{array}$ & $\begin{array}{l}\text { Lack of clarity of roles and } \\
\text { responsibilities in waste management } \\
\text { and working procedures. }\end{array}$ & $\begin{array}{l}\text { Gruber et al. (2016), } \\
\text { Mena et al. (2011) }\end{array}$ \\
\hline & $\begin{array}{l}\text { Lack of operational } \\
\text { control }\end{array}$ & $\begin{array}{l}\text { Lack of control of product entries and } \\
\text { exits, total sold and lost (especially } \\
\text { during promotions). }\end{array}$ & $\begin{array}{l}\text { Balaji \& Arshinder (2016), } \\
\text { Lebersorger \& Schneider } \\
\text { (2014), }\end{array}$ \\
\hline & Lack of quality standards & $\begin{array}{l}\text { Failure to comply with the retailer's } \\
\text { minimum food security requirements. }\end{array}$ & $\begin{array}{l}\text { Balaji \& Arshinder (2016), } \\
\text { Priefer et al. (2016) }\end{array}$ \\
\hline & Lack of stock rotation & $\begin{array}{l}\text { Lack of food rotation (shelf and } \\
\text { logistics center) to avoid g damaged / } \\
\text { crumpled items; possibility to remove } \\
\text { those not complying with quality } \\
\text { standards for donation and other } \\
\text { purposes. }\end{array}$ & $\begin{array}{l}\text { Canali et al. (2017), } \\
\text { Derqui et al. (2016), } \\
\text { Tromp et al. (2016) }\end{array}$ \\
\hline & $\begin{array}{l}\text { Poor inventory control/ } \\
\text { management policy }\end{array}$ & $\begin{array}{l}\text { Low performance in terms of } \\
\text { inventory control and management } \\
\text { (retail and logistics center). }\end{array}$ & $\begin{array}{l}\text { Balaji \& Arshinder (2016), } \\
\text { Gruber et al. (2016), } \\
\text { Holweg et al. (2016) }\end{array}$ \\
\hline & $\begin{array}{l}\text { Lack of coordination / } \\
\text { collaboration }\end{array}$ & $\begin{array}{l}\text { Lack of joint action and structured } \\
\text { action procedures among the chain's } \\
\text { members }\end{array}$ & $\begin{array}{l}\text { Aiello et al. (2015), Balaji \& } \\
\text { Arshinder (2016), Derqui et al. } \\
\text { (2016) }\end{array}$ \\
\hline & $\begin{array}{l}\text { Lack of information } \\
\text { sharing }\end{array}$ & $\begin{array}{l}\text { Weak or non-existent communication } \\
\text { and information sharing among the } \\
\text { chain's members }\end{array}$ & $\begin{array}{l}\text { Balaji \& Arshinder (2016), } \\
\text { Halloran et al. (2014), } \\
\text { Kaipia et al. (2013), Raak et al. } \\
(2017)\end{array}$ \\
\hline & $\begin{array}{l}\text { Problems with transport } \\
\text { and distribution } \\
\text { procedures }\end{array}$ & $\begin{array}{l}\text { Problems with transport and } \\
\text { distribution of the incoming food that } \\
\text { is sent to the retailer's stores. }\end{array}$ & $\begin{array}{l}\text { Giuseppe et al. (2014), } \\
\text { Mena et al. (2011), Raak et al. } \\
\text { (2017) }\end{array}$ \\
\hline $\begin{array}{l}\text { Group of } \\
\text { causes }\end{array}$ & Food waste causes & Definition & Authors \\
\hline
\end{tabular}


Table 2. Continued...

\begin{tabular}{|c|c|c|c|}
\hline $\begin{array}{l}\text { Group of } \\
\text { causes }\end{array}$ & Food waste causes & Definition & Authors \\
\hline \multirow[t]{4}{*}{$\begin{array}{c}\text { Method } \\
\text { (procedure) }\end{array}$} & $\begin{array}{l}\text { Weak logistics } \\
\text { infrastructure }\end{array}$ & $\begin{array}{l}\text { Failures and restrictions related to } \\
\text { logistics and store operations. }\end{array}$ & Holweg et al. (2016) \\
\hline & $\begin{array}{l}\text { Poor logistics network } \\
\text { design }\end{array}$ & $\begin{array}{l}\text { The network is designed with failures, } \\
\text { and the more intermediates exist } \\
\text { between the production and final sale, } \\
\text { the more the product will have to be } \\
\text { stored and handled, leading to possible } \\
\text { losses. }\end{array}$ & $\begin{array}{l}\text { Balaji \& Arshinder (2016), } \\
\text { Brancoli et al. (2017) }\end{array}$ \\
\hline & $\begin{array}{l}\text { Inadequate work } \\
\text { procedures }\end{array}$ & $\begin{array}{l}\text { Inadequate procedures for receiving, } \\
\text { handling, transporting, and delivering. }\end{array}$ & $\begin{array}{l}\text { Balaji \& Arshinder (2016), } \\
\text { Bilska et al. (2016), Mena et al. } \\
\text { (2011), }\end{array}$ \\
\hline & $\begin{array}{l}\text { Lack of integrated TI } \\
\text { systems }\end{array}$ & $\begin{array}{l}\text { Integrated IT systems that allow } \\
\text { the entire organization to have food } \\
\text { monitoring, from its entry to its exit. }\end{array}$ & Balaji \& Arshinder (2016) \\
\hline \multirow[t]{4}{*}{ People } & Lack of training & $\begin{array}{l}\text { Poor training, information and } \\
\text { education of workers, especially with } \\
\text { regard to handling and stacking. }\end{array}$ & $\begin{array}{l}\text { Balaji \& Arshinder (2016), } \\
\text { Girotto et al. (2015) }\end{array}$ \\
\hline & Lack of knowledge & $\begin{array}{l}\text { Low level of knowledge and } \\
\text { qualifications with regard to food. }\end{array}$ & $\begin{array}{l}\text { Balaji \& Arshinder (2016), } \\
\text { Bilska et al. (2016), } \\
\text { Gruber et al. (2016) }\end{array}$ \\
\hline & Lack of commitment & $\begin{array}{l}\text { Negligence of persons (employees and } \\
\text { management) involved in the system. }\end{array}$ & $\begin{array}{l}\text { Warshawsky (2015), } \\
\text { Gruber et al. (2016) }\end{array}$ \\
\hline & Incorrect handling & $\begin{array}{l}\text { Improper handling or handling is in the } \\
\text { shops, transportation or logistics center. }\end{array}$ & $\begin{array}{l}\text { Balaji \& Arshinder (2016), } \\
\text { Mena et al. (2011) }\end{array}$ \\
\hline \multirow[t]{2}{*}{ Materials } & Inadequate packaging & $\begin{array}{l}\text { Inadequate transport or storage } \\
\text { packaging, lack of modernization, } \\
\text { inaccurate labeling of information } \\
\text { about shelf life and expiration date. }\end{array}$ & $\begin{array}{l}\text { Balaji \& Arshinder (2016), } \\
\text { Mena et al. (2014), Tromp et al. } \\
\text { (2016) }\end{array}$ \\
\hline & Short shelf life & $\begin{array}{l}\text { Limited life time due to the short shelf } \\
\text { life and natural perishability of the } \\
\text { products. }\end{array}$ & $\begin{array}{l}\text { Garrone et al. (2014), } \\
\text { Kaipia et al. (2013), } \\
\text { Tromp et al. (2016) }\end{array}$ \\
\hline \multirow[t]{5}{*}{ Environment } & Climate changes & $\begin{array}{l}\text { Climatic events may impose } \\
\text { restrictions on the prevention of waste } \\
\text { or hinder the harvest of a particular } \\
\text { product. }\end{array}$ & $\begin{array}{l}\text { Mena et al. (2011), Shafiee- } \\
\text { Jood \& Cai (2016) }\end{array}$ \\
\hline & Eating habits & $\begin{array}{l}\text { Good and bad foods for health, food } \\
\text { controversies. }\end{array}$ & $\begin{array}{l}\text { Göbel et al. (2015), } \\
\text { Gruber et al. (2016) }\end{array}$ \\
\hline & Very strict laws & $\begin{array}{l}\text { Restriction to donate food, unsold } \\
\text { leftovers and other laws }\end{array}$ & $\begin{array}{l}\text { Gruber et al. (2016), } \\
\text { Priefer et al. (2016) }\end{array}$ \\
\hline & $\begin{array}{l}\text { Excessive stakeholder } \\
\text { pressure }\end{array}$ & $\begin{array}{l}\text { Pressures from government, NGOs, } \\
\text { and shareholders regarding waste. }\end{array}$ & $\begin{array}{l}\text { Canali et al. (2017), } \\
\text { Derqui et al. (2016) }\end{array}$ \\
\hline & Problems with seasonality & $\begin{array}{l}\text { Lack of skill in dealing or difficulty } \\
\text { controlling supply. }\end{array}$ & $\begin{array}{l}\text { Mena et al. (2011), Mena et al. } \\
\text { (2014) }\end{array}$ \\
\hline \multirow[t]{4}{*}{ Measurement } & $\begin{array}{l}\text { Inadequate demand } \\
\text { forecasting }\end{array}$ & $\begin{array}{l}\text { Demand forecasting failure due to } \\
\text { uncertainty or lack of availability of } \\
\text { accurate data. }\end{array}$ & $\begin{array}{l}\text { Balaji \& Arshinder (2016), } \\
\text { Mena et al. (2011), Tromp et al. } \\
\text { (2016) }\end{array}$ \\
\hline & Sudden order changes & $\begin{array}{l}\text { Inflexibility regarding ordering or } \\
\text { returning quickly, mainly due to } \\
\text { promotions or high demand. }\end{array}$ & Mena et al. (2014) \\
\hline & Excess production & $\begin{array}{l}\text { Excessive "requests" only to provide } \\
\text { food in abundance, lack of measures to } \\
\text { control production and surplus. }\end{array}$ & $\begin{array}{l}\text { Bilska et al. (2016), Mena et al. } \\
\text { (2011) }\end{array}$ \\
\hline & $\begin{array}{l}\text { Lack of waste } \\
\text { measurement }\end{array}$ & $\begin{array}{l}\text { Lack of information and data on } \\
\text { the amount and location of waste; } \\
\text { difficulty to determine how much is } \\
\text { being lost. }\end{array}$ & $\begin{array}{l}\text { Derqui et al. (2016), } \\
\text { Ghosh et al. (2016) }\end{array}$ \\
\hline
\end{tabular}


To create the fishbone diagram, we considered that the causes of waste can be classified into six groups: machines (problems such as processing equipment, lack of maintenance, failures, etc.); methods (used to perform the job or a procedure, incorrect or improperly applied processes); manpower (problems with people involved in the process, such as actions or level of qualification); materials (problems with the materials used in the process, such as the raw material); environment (related to the process environment, such as climatic, political and market factors) and measurement (assessments made in the process, such as measurement or inaccurate data collection) (Ishikawa, 1986; Kume, 1993).

\section{Supply chain resilience}

Disruptions in the flow of goods, services and/or information are sudden and unexpected events that can generate impacts that can lead a supply chain to fail in its mission to deliver products and / or services to its customers according to defined locations, quantities, time and costs (Blackhurst et al., 2011; Svensson, 2003). There are several sources of risk of rupture: terrorist, nuclear, chemical or biological attacks, cyber terrorism; natural disasters and sudden climate change; industrial and transport accidents; strikes, and external problems (changes in government spending, lifestyle, and manufacturing technology) (Stecke \& Kumar, 2009). Silvestre (2015) identified the following sources of distinct risks in the Brazilian context: corruption, social pressures, lack of transparency and a high degree of complexity.

Supply chains are under continuous threat, and a strategy for the survival of organizations is the development of resilience. This is defined as the adaptive capacity of a supply chain to withstand and cope with unexpected events (ruptures), maintaining control over its structure and functions, and enabling recovery and response to such disruptions, in order to restore the chain to its original operations or improve them (Christopher \& Peck, 2004; Kamalahmadi $\&$ Parast, 2016). A number of discussions that can contribute to the construction of resilience (Blackhurst et al., 2011; Christopher \& Peck, 2004; Kamalahmadi \& Parast, 2016; Pereira et al., 2014). In this study, we chose the term "element" as something that assists in the development of practices for anticipation, response and recovery of ruptures. Therefore, these elements may be associated with events that precede, occur during or after ruptures, as raised by Ali et al. (2017). Table 3 presents the identified elements as well as a brief definition of each.

Table 3. Elements that create resilience.

\begin{tabular}{|c|c|c|}
\hline Elements & Definition & Authors \\
\hline Agility & $\begin{array}{l}\text { Quick decision-making and adaptations needed to recover } \\
\text { from disruptions }\end{array}$ & $\begin{array}{l}\text { Kamalahmadi \& Parast (2016), } \\
\text { Jüttner \& Maklan (2011) }\end{array}$ \\
\hline Collaboration & $\begin{array}{l}\text { Ability to work effectively with another entity to obtain } \\
\text { mutual benefit in situations related to the ruptures }\end{array}$ & $\begin{array}{l}\text { Johnson et al. (2013), Pettit et al. } \\
\text { (2010), Papadopoulos et al. (2017) }\end{array}$ \\
\hline Communication & $\begin{array}{l}\text { Information exchange in order to reduce asymmetry } \\
\text { between the manufacturer and its suppliers }\end{array}$ & $\begin{array}{l}\text { Wieland \& Wallenburg (2013), } \\
\text { Papadopoulos et al. (2017) }\end{array}$ \\
\hline Financial Strength & $\begin{array}{l}\text { Ability to absorb possible fluctuations in the company's } \\
\text { cash flow from its financial strength, enabling the } \\
\text { provision of economic incentives and maintenance of } \\
\text { additional suppliers. }\end{array}$ & $\begin{array}{l}\text { Hohenstein et al. (2015), } \\
\text { Tukamuhabwa et al. (2015), } \\
\text { Pettit et al. (2010), Zhang et al. } \\
\text { (2011) }\end{array}$ \\
\hline Flexibility & $\begin{array}{l}\text { Ability to change a process, product / supplier or client / } \\
\text { logistic network, generating the minimum possible impact } \\
\text { in order to recover from a break. }\end{array}$ & $\begin{array}{l}\text { Chang et al. (2015), Kamalahmadi } \\
\text { \& Parast (2016) }\end{array}$ \\
\hline Innovation & $\begin{array}{l}\text { Process of creation / adoption new products, improvement } \\
\text { or technology by the adopting organization. It assists the } \\
\text { recovery of ruptures when the innovation aims to avoid } \\
\text { the use of a certain raw material or process, or when } \\
\text { a new product is generated to withstand the negative } \\
\text { impacts of a rupture }\end{array}$ & $\begin{array}{l}\text { Golgeci \& Ponomarov } \\
\text { (2013), Khan et al. (2012), } \\
\text { Tukamuhabwa et al. (2015), } \\
\text { Kamalahmadi \& Parast (2016) }\end{array}$ \\
\hline Leadership & $\begin{array}{l}\text { Commitment and support of the company's leadership } \\
\text { with the resilience of the chain. }\end{array}$ & $\begin{array}{l}\text { Christopher \& Peck (2004), } \\
\text { Scholten et al. (2014), } \\
\text { Kamalahmadi \& Parast (2016) }\end{array}$ \\
\hline $\begin{array}{l}\text { Knowledge } \\
\text { management }\end{array}$ & $\begin{array}{l}\text { It also involves the review of the company's leadership } \\
\text { policies and factors related to the knowledge accumulated } \\
\text { by managers for more effective actions in rupture events, } \\
\text { especially when they are similar to those previously } \\
\text { occurred }\end{array}$ & $\begin{array}{l}\text { Scholten et al. (2014), Sahu et al. } \\
(2017)\end{array}$ \\
\hline
\end{tabular}


Table 3. Continued...

\begin{tabular}{|c|c|c|}
\hline Elements & Definition & Authors \\
\hline Redundancy & $\begin{array}{l}\text { Redundancy is the overlap of operations, processes, } \\
\text { products, suppliers or systems, from an extra pre-existing } \\
\text { capacity, which is triggered from a break. This surplus } \\
\text { capacity can be used during times of rupture. }\end{array}$ & $\begin{array}{l}\text { Scholten et al. (2014), Soni et al. } \\
(2014), \text { Kamalahmadi \& Parast } \\
(2016,2017)\end{array}$ \\
\hline Risk management & $\begin{array}{l}\text { Elements of risk management are spread throughout } \\
\text { the company. Risk management consists of monitoring, } \\
\text { knowledge and prevention of risks to rupture }\end{array}$ & $\begin{array}{l}\text { Christopher \& Peck (2004), } \\
\text { Tukamuhabwa et al. (2015), } \\
\text { Kamalahmadi \& Parast (2016) }\end{array}$ \\
\hline $\begin{array}{l}\text { Security } \\
\text { Technologies }\end{array}$ & $\begin{array}{l}\text { Advance defense mechanisms such as automatic } \\
\text { identification, cameras, global positioning (GPS), } \\
\text { methods involving X-ray, and computer-related security. }\end{array}$ & $\begin{array}{l}\text { Rajesh \& Ravi (2015), } \\
\text { Zhang et al. (2016) }\end{array}$ \\
\hline $\begin{array}{l}\text { Supply chain } \\
\text { structure }\end{array}$ & $\begin{array}{l}\text { Organization of the chain, including factors such } \\
\text { as distance from suppliers, company location and } \\
\text { transportation infrastructure. It can be changed to build } \\
\text { resiliency in processes and to reduce exposure of the } \\
\text { supply chain to risk }\end{array}$ & $\begin{array}{l}\text { Blackhurst et al. (2011), } \\
\text { Hohenstein et al. (2015), } \\
\text { Kamalahmadi \& Parast (2016) }\end{array}$ \\
\hline Trust & $\begin{array}{l}\text { Trust that exists among members of the chain. It } \\
\text { refers to the expectation that the partner will not act } \\
\text { opportunistically, fulfilling what has been agreed and } \\
\text { contributing to the chain. }\end{array}$ & $\begin{array}{l}\text { Christopher \& Lee (2004), } \\
\text { Kamalahmadi \& Parast (2016) }\end{array}$ \\
\hline Visibility & $\begin{array}{l}\text { The understanding that the company has about its supply } \\
\text { chain, clearly seeing the chain; it allows the identification } \\
\text { of risks and resources to overcome ruptures and mitigate } \\
\text { their effects. }\end{array}$ & $\begin{array}{l}\text { Blackhurst et al. (2011), } \\
\text { Pettit et al. }(2013), \text { Kamalahmadi } \\
\text { \& Parast }(2016,2017)\end{array}$ \\
\hline
\end{tabular}

\section{Results and discussions}

The overall results of this study are summarized in Table 4, which will be discussed in this section. It presents the causes of waste identified, their frequency of citation, the authors who cited them and the elements of resilience that most influenced them (positively and negatively). The most frequently addresses causes were methods (170 mentions), measurement (61), and machine (58), accounting for about $70 \%$ of the total. This result points to a set of causes mostly internal to the retail, in which it has great possibility of action and solution. As for the elements of resilience that influence (positively or negatively) each group of causes, these are presented in sequence with emphasis only on the three with the most positive influence, as well as on those that influence negatively.

Figure 2 shows the elements related to the Machine cause group. The four main elements observed that positively influence the causes of wastage of this group are: Supply Chain Structure, Security Technology, Innovation and Visibility.

A factor that can relate Supply Chain Structure to the Machine cause is the waste generated by transport over long distances. This type of loss occurs mainly in products that require refrigeration, such as perishables, when transport time directly impacts the waste (Bernstad et al., 2017; Garrone et al., 2014). The absence of Security Technologies that control and/or modify food temperature during transport and storage, as well as the absence or inefficiency of tracking mechanisms, prevents retailers from properly monitoring food. In addition, the safety of the equipment can be monitored in the cold chain (Derqui et al., 2016; Kamalahmadi \& Parast, 2016).

Innovation mainly influences the causes cold chain breaking and lack of refrigerated transport, and may be related to improved equipment supervision and control. The creation, adoption, or improvement of products and/or processes, such as temperature control technologies, refrigerated trucks and systems, can assist retailers in preventing and/or reducing possible causes of waste in this group (Garrone et al., 2014).

Finally, the influence of Visibility in this group of causes can contribute to the knowledge and functionality of the equipment and transports used. In order to operate effectively, companies must have at their disposal resources and equipment adapted to their processes, since they can constantly monitor problems in storage and transport equipment in the cold chain (Bilska et al., 2016).

In contrast, the Redundancy element acts as a barrier to the reduction of the Machine cause, since the excess of equipment and routes and/or storage capacity can make it difficult to control operations, provoking food deterioration and waste.

Figure 3 presents the elements related to the Methods cause, being the most influential: Communication, Supply Chain Structure and Trust. Communication can influence the reduction of method-related causes 


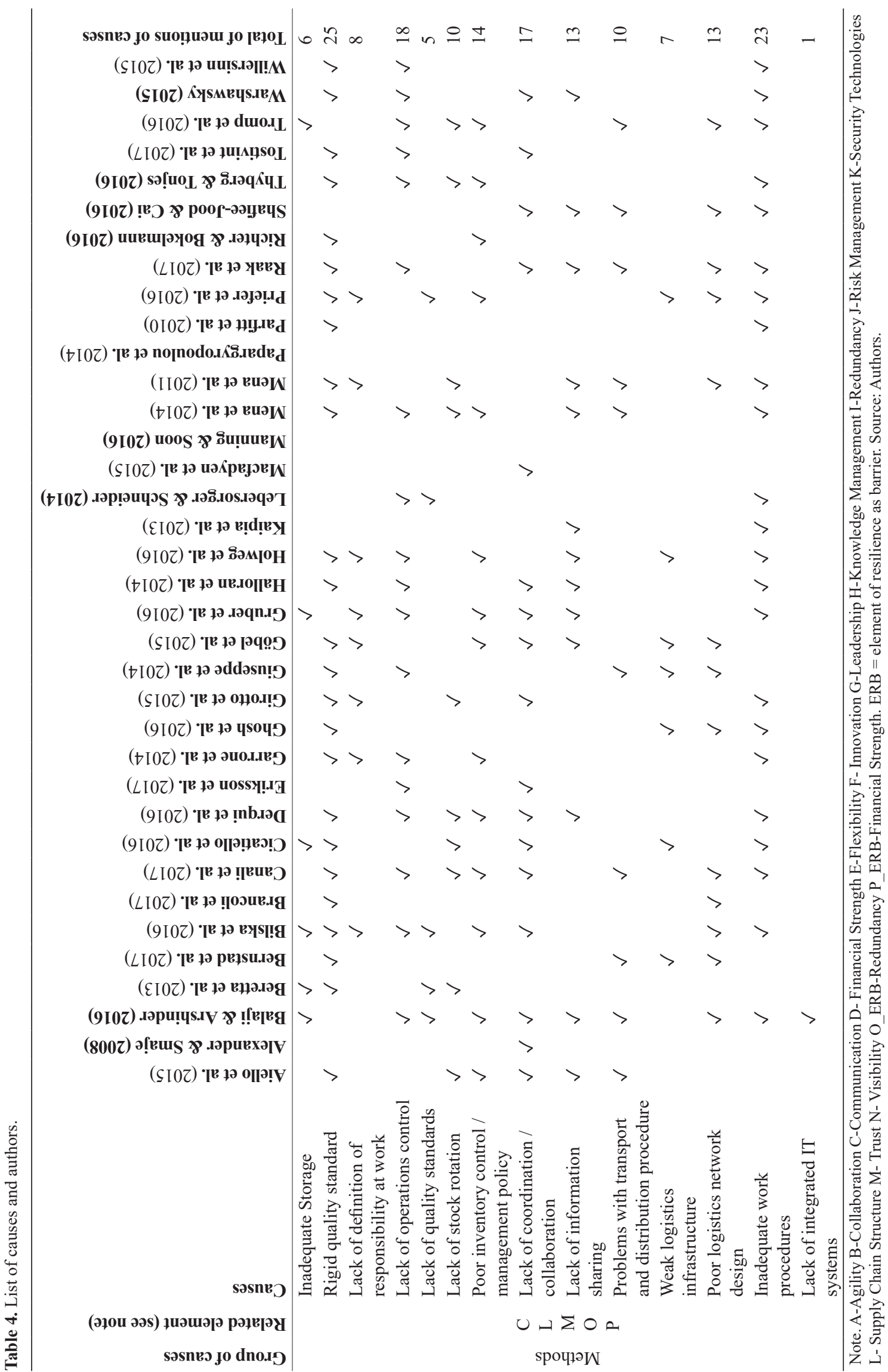




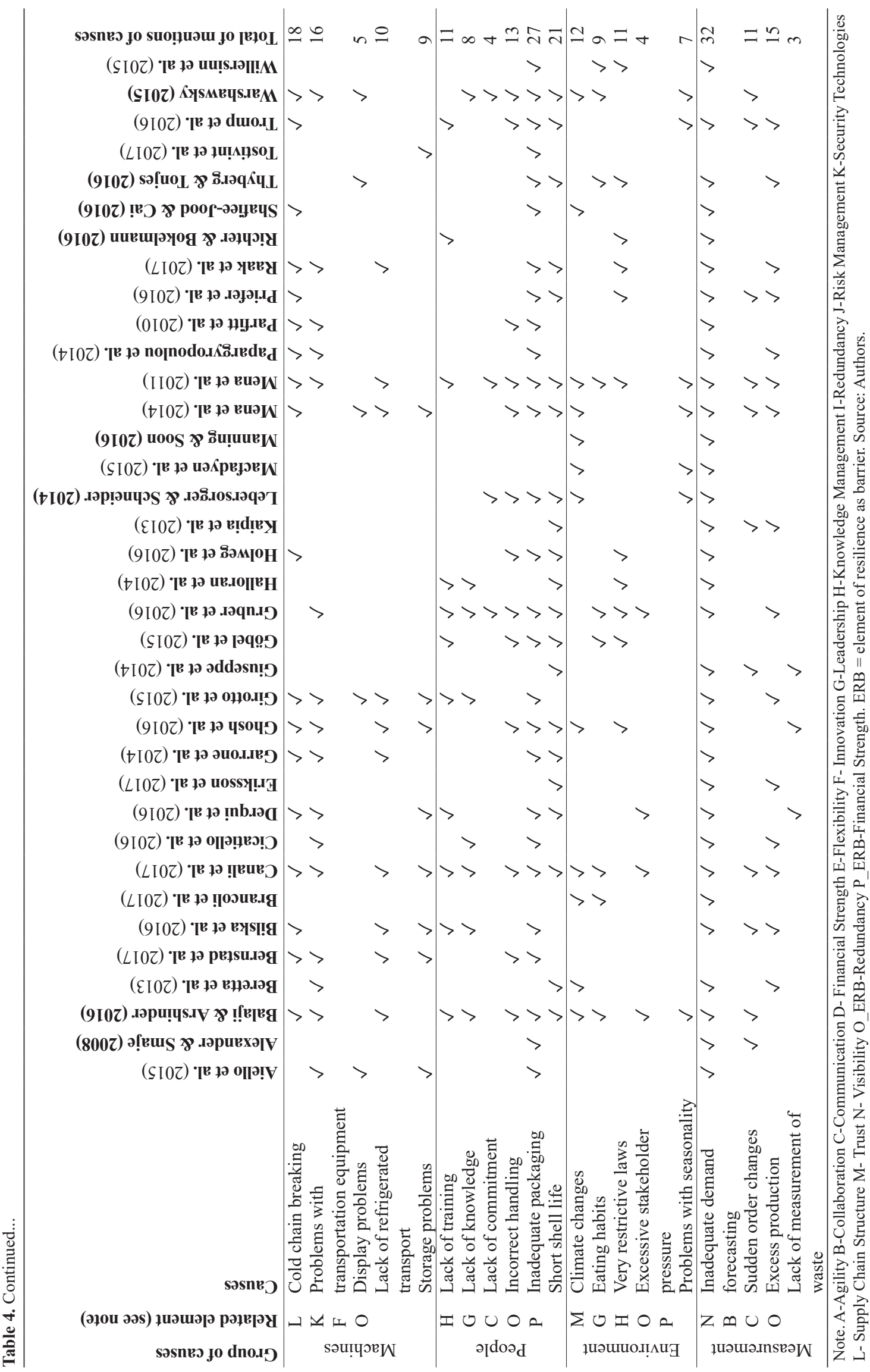




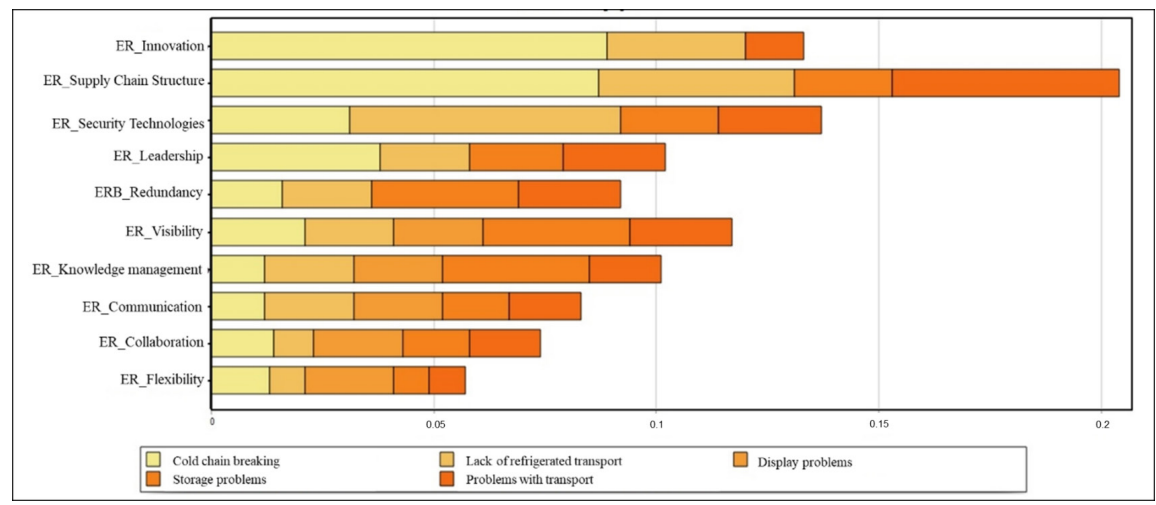

Figure 2. Waste-related elements: machine cause.

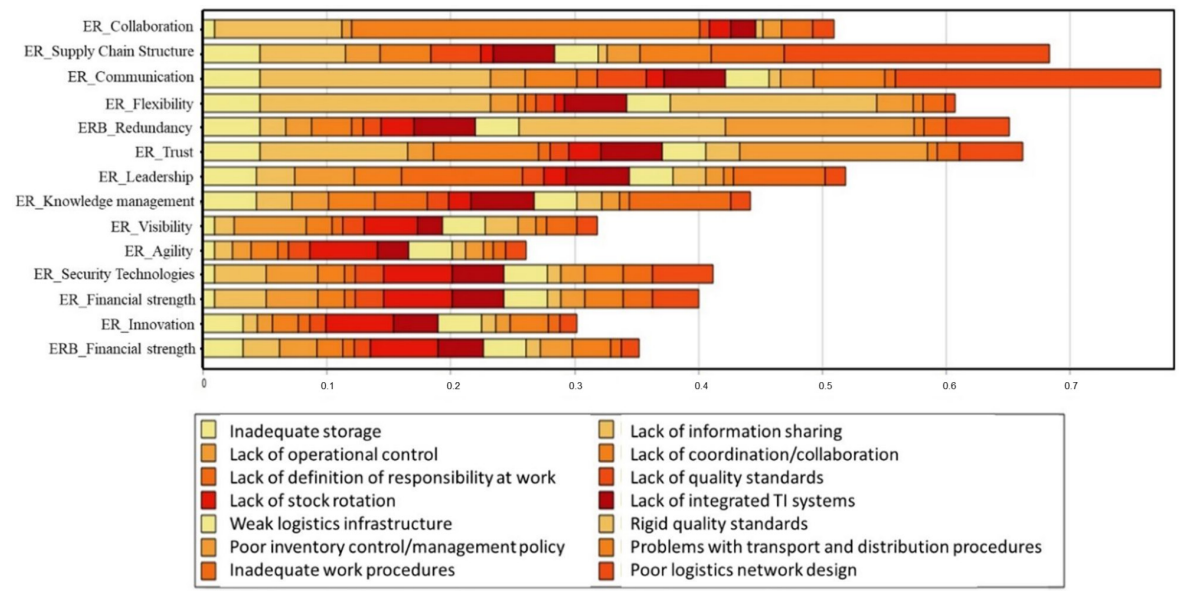

Figure 3. Waste-related elements: methods cause.

of waste, mainly by allowing a better exchange of information between supply chain members and the retailer. This makes for clearer and more defined work procedures, for example, and improves the sharing of information about product quality standards.

Supply Chain Structure impacts on the reduction of waste mainly due to the causes related to 'poor logistics network design', 'problems with transport and distribution procedure' and 'poor inventory control/management policy'. In the case of perishable foods, logistical issues should be well structured to provide quality and fast delivery, allowing unsold products to be redirected to other markets (donations, for example) as quickly as possible. Holweg et al. (2016) have argued that a retailer's supply chain and logistics processes do not end at the point of sale, requiring both theoretical and practical considerations. Trust is mainly linked to 'lack of information sharing' and to 'lack of coordination/collaboration', since, for Mena et al. (2011), bad practices of information sharing do not only create waste, but also weaken trust in the information exchanged.
As a barrier, the relationship of the redundancy element with the "poor inventory control/management policy", cause involved the maintenance of a safety inventory. Managers often request more than the expected quantity to serve as a temporary safety stock (Gruber et al., 2016). In their studies, Mena et al. (2014) identified a tendency to over stock just in case, prioritizing 'product loss over lack of its availability. The same authors point out that a change in this behavior would contribute to waste reduction.

Figure 4 presents the elements related to the People cause, in which Knowledge Management, Leadership and Communication have a positive impact. Knowledge Management allows the knowledge accumulated by managers to be passed on to employees and other members of the chain for more effective action when waste occurs. Without Leadership support, employee training and commitment to waste may be neglected.

Through leadership, managers can influence decisions and activities that can be wasteful. Store managers need to understand that the behavior and commitment of their employees influence the occurrence of waste 


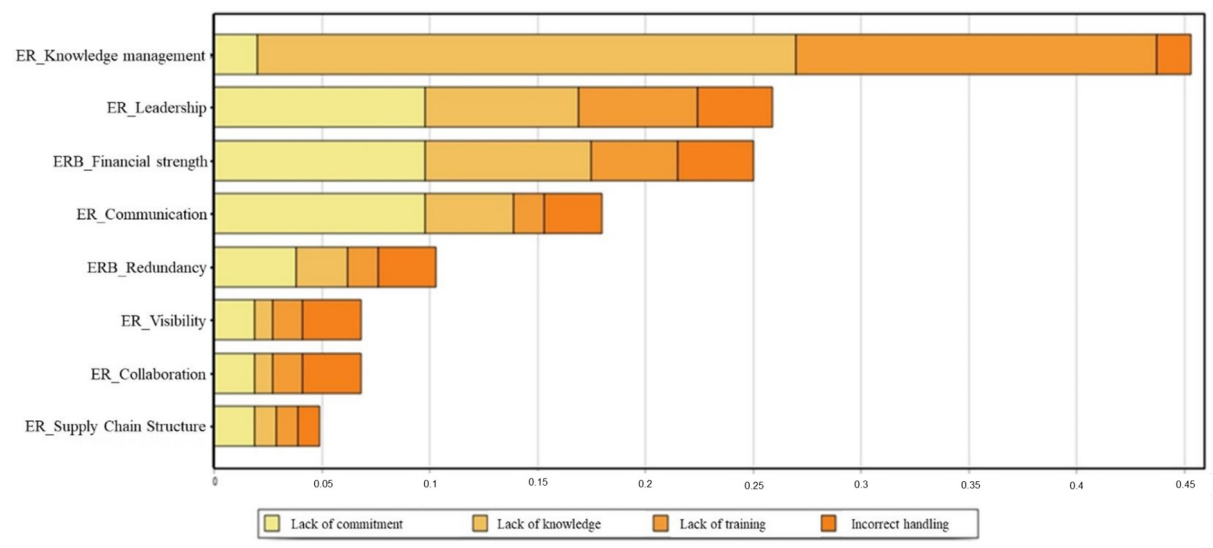

Figure 4. Waste-related elements: people cause.

(Alexander \& Smaje, 2008; Gruber et al., 2016). Thus, it is necessary to educate employees about food safety and waste prevention practices in their daily workplaces, creating an ability to anticipate the causes of this type of waste (Bilska et al., 2016).

Holweg et al. (2016) posited that a high experience level, particularly among store managers, represents an opportunity for ideas and solutions to be developed. Active involvement in developing new processes contributes to better solutions for making the necessary behavioral changes and increasing overall job satisfaction among waste management employees. Communication allows the exchange of knowledge and work procedures to be passed on in a clear way, and can increase the commitment of all to avoid and/or reduce waste. Kaipia et al. (2013) found that improved communication and supply chain collaboration can reduce costs and waste throughout the chain, whereas Financial Strength problems element can have a negative impact on the lack of investment in training and benefits for the labor force. Redundancy acts as a barrier because it can lead to more people being trained and a difficulty in assigning tasks, leading to incorrect handling or lack of commitment.

Figure 5 presents the main elements of the Materials: Agility, Innovation, and Supply Chain Structure. Agility directly influences the short shelf life cause and allows the necessary decision making and adaptations in the materials to be made quickly so that food arrives fresh in the retailer's stores, avoiding possible causes of such waste (Garrone et al., 2014). For Balaji \& Arshinder (2016), information about shelf life loss behavior based on continuous chain monitoring enables fast responses in adjusting and correcting transport processes before products fall below acceptable levels of quality. Also, innovations in packaging design offer better food quality monitoring during transport and storage, increased food protection during transport and a longer shelf life (Shafiee-Jood
\& Cai, 2016). The complex relationships among supply chain participants depend on the alignment around a shared vision for sustainable development and innovation through intersectoral approaches (Derqui et al., 2016).

Regarding the supply chain structure, the main waste derives from refrigerated, long-distance transport of perishable, short-life products. In this case, transport time has a direct impact on wastage (Garrone et al., 2014; Girotto et al., 2015; Bernstad et al., 2017).

Redundancy can act negatively in reducing this cause, due to the excess of processes and inefficient materials that reduce the shelf life of the products, causing waste even before the foods reach the expiration date.

Figure 6 shows that the elements that most influence the Environment cause are Trust, Leadership and Knowledge Management. Trust allows the exchange of information between a company and its stakeholders. A lack of trust between retailers and suppliers may lead to a breach of order agreements between the parties (Halloran et al., 2014). Moreover, lack of trust may reflect on consumers who demand high cosmetic standards and may suspect retailers 'manipulation to sell products (Warshawsky, 2015).

Leadership has both internal (top management support) and external impacts, given the retail's power over the chain and the political-legal environment. It is the managers' commitment to develop and implement a quality policy, setting measurable reduction targets for the entire organization, conducting regular management reviews and ensuring adequate resources to reduce and prevent the causes of waste (Bilska et al., 2016). These responsibilities should be aligned with the environment.

Knowledge management reflects the need for organizations to share information with the other chain links, otherwise knowledge tends to be retained by some individuals (Canali et al., 2017; Halloran et al., 2014). Knowledge management is essential for information 




Figure 5. Waste-related elements: materials cause.

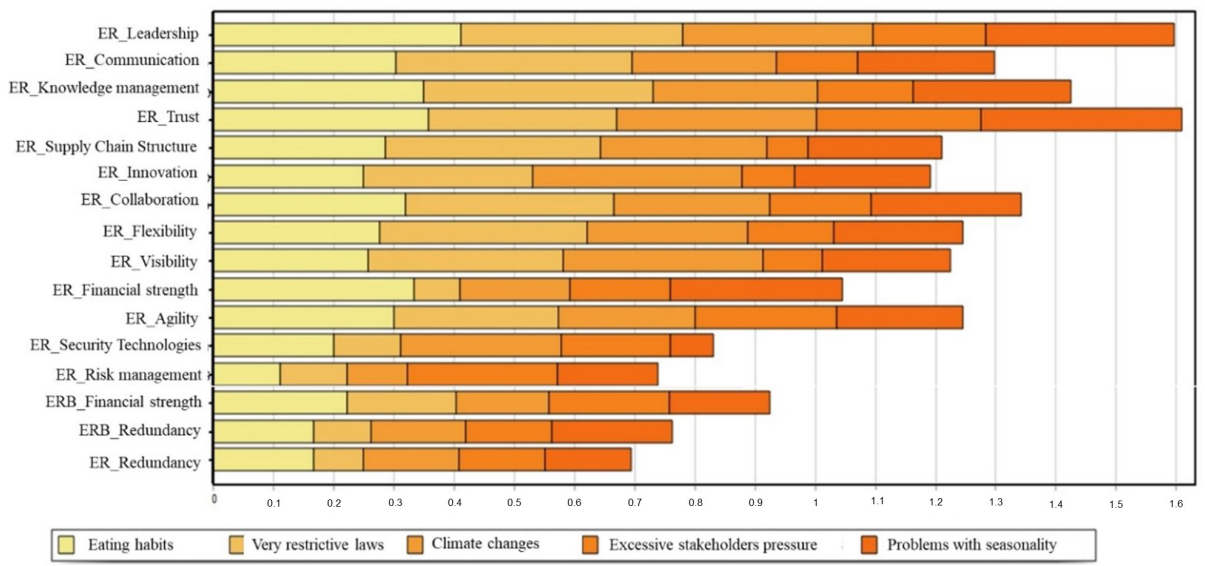

Figure 6. Waste-related elements: environment cause.

on climatic, crop or phytosanitary matters to be known to all the links in the chain, so actions can be taken to reduce waste. For example, based on the knowledge about a climatic issue that impacts the quality of a particular product, retailers choose to reduce the quantity of ordered items.

As barriers, while Financial Strength can restrict various investments, Redundancy can influence the acquisition of products from other regions to meet needs, which, besides being more expensive, can deteriorate before reaching the point of sale.

Finally, Figure 7 presents the elements that most influence the Measurement cause: Visibility, Collaboration, Communication and Supply Chain Structure. In the case of Visibility, the understanding of what the retailer needs allows a more accurate forecast of demand, and, consequently, less food surplus. In addition, Visibility can help the retailer identify where the biggest wastes occur in and out of stores, seek prevention and reduction actions. According to Mena et al. (2011), close collaboration between retailers and their suppliers allows an initial step to deal with most causes of waste, which improves information sharing, increases the accuracy of demand and production forecasts, and improve promotion managements. Good communication helps to plan production and makes demand forecasting easier, thus avoiding one of the most common reasons for waste (Kaipia et al., 2013).

In relation to the supply chain structure, the longer the distances between suppliers and retailers, the greater the related waste. In this way, chain complexity can arise due to the presence of a large number of links and interactions between them, which may make it difficult to respond to sudden changes in orders, and cause an excess of production (Mena et al., 2014).

Redundancy acts as a barrier to reducing food waste in retail when related to the Measurement cause. This can be explained by the overlap of operations, processes or systems. Many retailers opt to place orders in larger quantities, even though they have no demand for them. Mena et al. (2014) reported in their study that retailers promoted high levels of security stock, which in many cases led to short shelf life. 


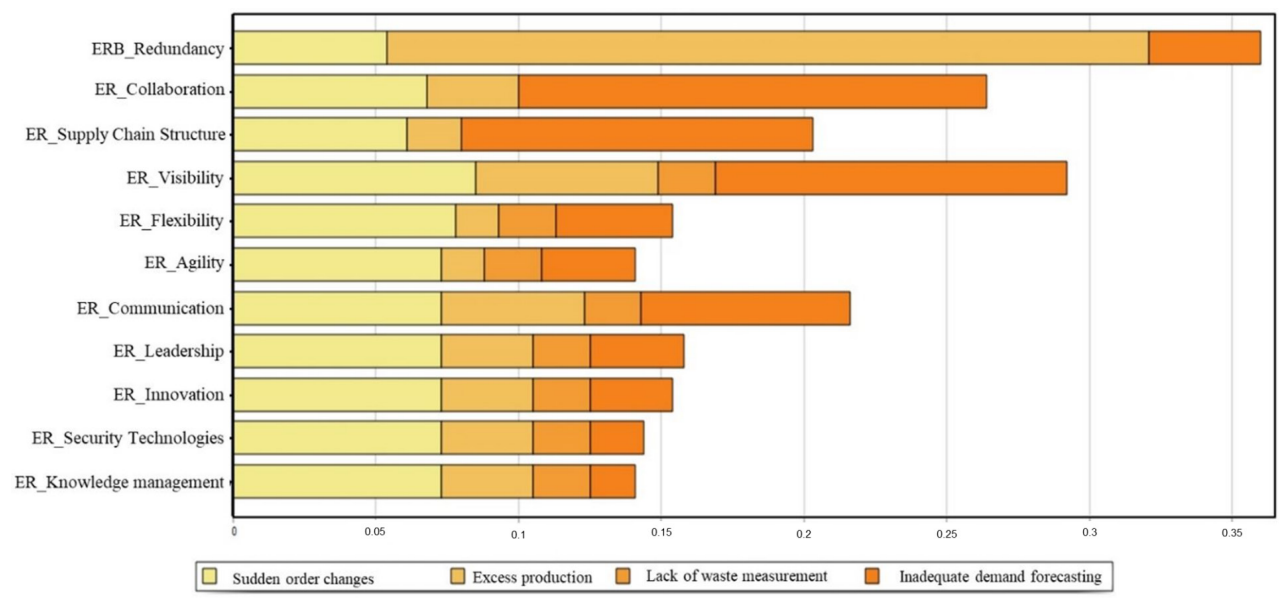

Figure 7. Waste-related elements: measurement cause.

\section{ELEMENTS OF RESILIENCE}

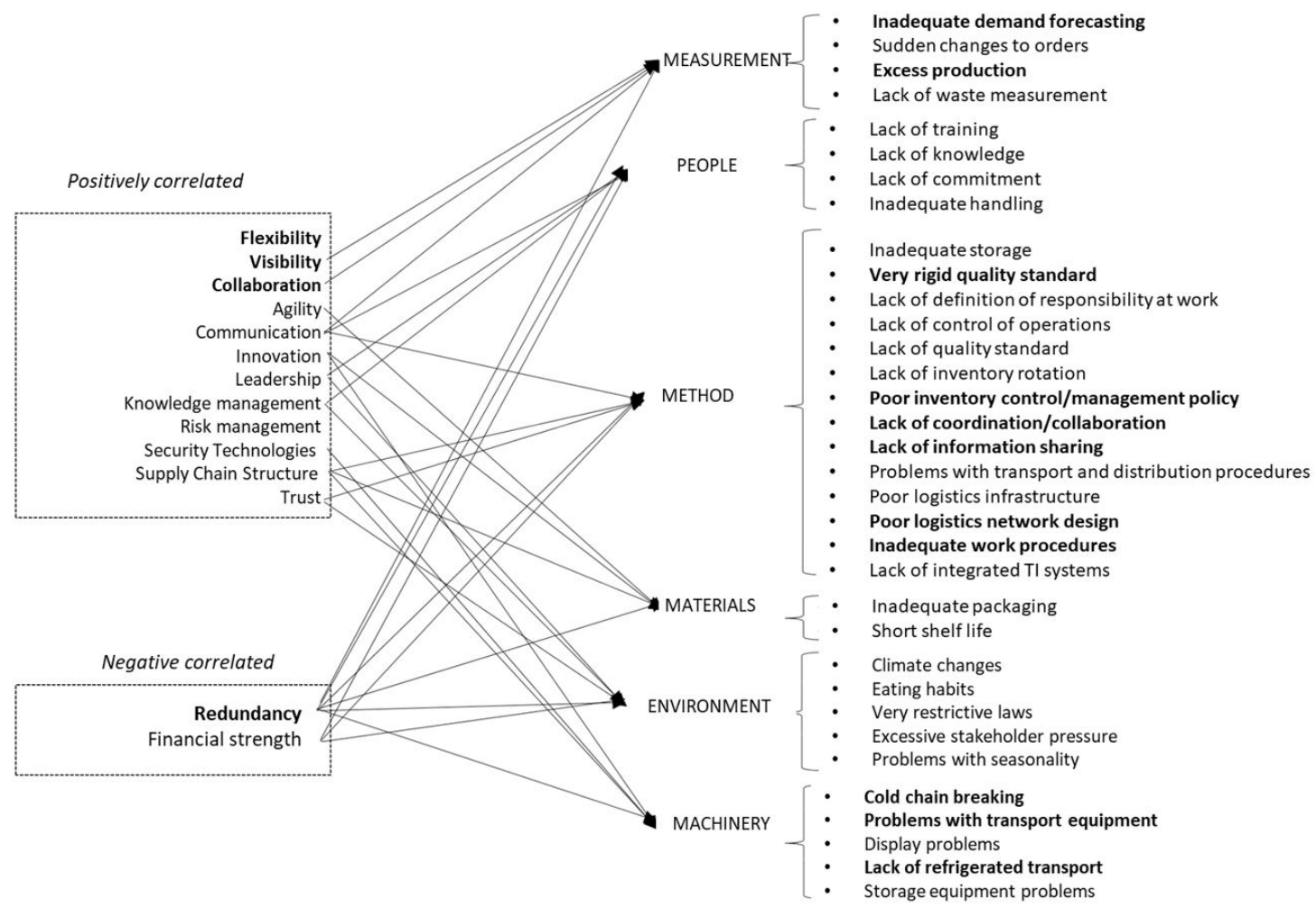

\section{WASTE CAUSES}

Inadequate demand forecastin

Lack of training

Lack of knowledge

Lack of commitmen

nadequate storage

Lack of control of operations

ack of qualitystandard

ack of inventory rotatio

Lack of coordination/collaboration

Lack of information sharing

Poor logistics network desig

Inadequate work procedure

Figure 8. Links between resilience elements and waste causes.

Göbel et al. (2015) emphasize the fact that the wasted in fruits and vegetables usually have little significant costs, therefore networks prefer to waste them than to risk not having products available.

Figure 8 summarizes the relationships identified between resilience elements and causes of food waste according to the discussions raised. The elements of resilience in bold most influence the waste causes, according to the content analysis of the literature. The causes in bold are those that were most cited by the authors surveyed according to Table 4. Finally, the arrows indicate the three elements that most influenced positively in each group of causes of waste and the elements that influenced negatively, that is, that represented barriers to the minimization of the causes of waste. 


\section{Final considerations}

The literature review conducted by this study showed that the elements of resilience can positively or negatively influence the causes of waste in the retail. The redundancy and financial strength elements were identified as possible barriers to reducing the causes of waste (negative influence), while the others could help in this reduction (positive influence). Flexibility, visibility and collaboration are the most frequently mentioned in texts, which may indicate that they tend to have a greater contribution to reducing the main causes of waste.

Because flexibility develops the ability to change resources quickly and efficiently, it can: help retailers adapt to a new process that reduces or prevents waste; change its logistics network - redirecting suppliers to avoid long distances in the transportation of perishable foods; modify the location or forms of transport; or even redirect products with a short expiration date to other markets, therefore preventing their waste. Visibility allows retailers to identify possible actions along the chain that could generate waste to identify anticipation and mitigation resources.

Collaboration, one of the initial elements in resilience generation (Christopher \& Peck, 2004; Kamalahmadi \& Parast, 2016), becomes necessary to work effectively with other organizations to reduce food waste. This element may encourage companies to consider sustainability issues in decision-making, especially taking into account that initiatives to reduce waste at one level of the chain may adversely affect another. The causes of waste most mentioned in the text were related to Measurement (inadequate forecasting of demand), Materials (inadequate packaging and short shelf life) and Method (rigid quality standard and inadequate work procedures).

To help solve food waste problems, it is necessary to create actions that go beyond reducing their causes, focused on prevention and anticipation concepts drawn from the literature on resilience. A contribution to the area of food waste, considering the results of Ali et al. (2017) on resilience skills, is that most of the elements that create resilience found in this SLR contribute to minimize causes of waste related to the anticipation phase. This result is consistent within the context of food waste, since the shelf life of the food is short, and if food is not sold, processed or donated, it looses its value completely. Thus, as a theoretical analysis, it can be concluded that resilience positively influences food waste as a way for retailers to anticipate the causes of waste. However, as discussed, this influence is partial, since some of its elements prevent this reduction from actually being implemented.

Some limitations should be highlighted. The analyses of this study focused on retail, not encompassing other links in the chain. It is also based on the literature found in the three databases researched to date. Thus, the highlighted relationships represent concepts and relationships mentioned in the reviewed literature. Future works may deepen the relationships between the elements of resilience and waste causes considering other databases or empirically verifying the identified proximity. Empirical studies could better define or that find new connections between elements and causes in different links in the food chain. Other interesting supply chains to research this subject could be fast-fashion or electronics. Future studies could further explore the impact of reducing waste on costs and increased food availability.

\section{References}

Aiello, G., Enea, M., \& \& Muriana, C. (2015). Alternatives to the traditional waste management: food recovery for human non-profit organizations. International Journal of Operations and Quantitative Management, 21(3), 215-239.

Alexander, C., \& Smaje, C. (2008). Surplus retail food redistribution: an analysis of a third sector model. Resources, Conservation and Recycling, 52(11), 12901298. http://dx.doi.org/10.1016/j.resconrec.2008.07.009.

Ali, A., Mahfouz, A., \& Arisha, A. (2017). Analysing supply chain resilience: integrating the constructs in a concept mapping framework via a systematic literature review. Supply Chain Management, 22(1), 16-39. http://dx.doi. org/10.1108/SCM-06-2016-0197.

Badger, D., Nursten, J., Williams, P., \& Woodward, M. (2010). Should all literature reviews be systematic? Evaluation and Research in Education, 14(3-4), 220-230.

Balaji, M., \& Arshinder, K. (2016). Modeling the causes of food wastage in Indian perishable food supply chain. Resources, Conservation and Recycling, 114, 153-167. http://dx.doi.org/10.1016/j.resconrec.2016.07.016.

Bardin, L. (2008). Análise de conteúdo (70. ed.). Paris: Presses Universitaires de France.

Beretta, C., Stoessel, F., Baier, U., \& Hellweg, S. (2013). Quantifying food losses and the potential for reduction in Switzerland. Waste Management (New York, N.Y.), 33(3), 764-773. http://dx.doi.org/10.1016/j.wasman.2012.11.007. PMid:23270687.

Bernstad, A. K., Cánovas, A., \& Valle, R. (2017). Consideration of food wastage along the supply chain in lifecycle assessments: A mini-review based on the case of tomatoes. Waste Management \& Research, 35(1), 29-39. http://dx.doi.org/10.1177/0734242X16666945. PMid:27765884.

Bilska, B., Wrzosek, M., Kołożyn-Krajewska, D., \& Krajewski, K. (2016). Risk of food losses and potential of food recovery for social purposes. Waste Management (New York, N.Y.), 52, 269-277. http://dx.doi.org/10.1016/j. wasman.2016.03.035. PMid:27026493. 
Blackhurst, J., Dunn, K. S., \& Craighead, C. W. (2011). An empirically derived framework of global supply resiliency. Journal of Business Logistics, 32(4), 374-391. http://dx.doi.org/10.1111/j.0000-0000.2011.01032.x.

Brancoli, P., Rousta, K., \& Bolton, K. (2017). Life cycle assessment of supermarket food waste. Resources, Conservation and Recycling, 118, 39-46. http://dx.doi. org/10.1016/j.resconrec.2016.11.024.

Canali, M., Amani, P., Aramyan, L., Gheoldus, M., Moates, G., Östergren, K., Silvennoinen, K., Waldron, K., \& Vittuari, M. (2017). Food waste drivers in Europe, from Identification to possible interventions. Sustainability, 9(1), 1-33. http://dx.doi.org/10.3390/su9010037.

Chang, W., Ellinger, A. E., \& Blackhurst, J. (2015). A contextual approach to supply chain risk mitigation. International Journal of Logistics Management, 26(3), 642-656. http://dx.doi.org/10.1108/IJLM-02-2014-0026.

Christopher, M., \& Lee, H. (2004). Mitigating supply chain risk through improved confidence. International Journal of Physical Distribution \& Logistics Management, 34(5), 388-396. http://dx.doi.org/10.1108/09600030410545436.

Christopher, M., \& Peck, H. (2004). Building the resilient supply chain. International Journal of Logistics Management, 15(2), 1-13. http://dx.doi.org/10.1108/09574090410700275.

Cicatiello, C., Franco, S., Pancino, B., \& Blasi, E. (2016). The value of food waste: an exploratory study on retailing. Journal of Retailing and Consumer Services, 30, 96104. http://dx.doi.org/10.1016/j.jretconser.2016.01.004.

Denyer, D., \& Tranfield, D. (2009). Producing a systematic review. In D. A. Buchanan \& A. Bryman (Eds.), The $S A G E$ handbook of organizational research methods (pp. 671-689). London: Sage.

Derqui, B., Fayos, T., \& Fernandez, V. (2016). Towards a more sustainable food supply chain: opening up invisible waste in food service. Sustainability, 8(7), 1-20. http:// dx.doi.org/10.3390/su8070693.

Eriksson, M., Ghosh, R., Mattsson, L., \& Ismatov, A. (2017). Take-back agreements in the perspective of food waste generation at the supplier-retailer interface. Resources, Conservation and Recycling, 122, 83-93. http://dx.doi. org/10.1016/j.resconrec.2017.02.006.

Fahimnia, B., \& Jabbarzadeh, A. (2016). Marrying supply chain sustainability and resilience: A match made in heaven. Transportation Research Part E, Logistics and Transportation Review, 91, 306-324. http://dx.doi. org/10.1016/j.tre.2016.02.007.

Food and Agricultute Organization of the United Nations - FAO. (2013). Food wastage footprint. Impacts on natural resources. Retrieved in 2018, December 21, from http://www.fao.org/docrep/018/i3347e/i3347e.pdf

Food and Agriculture Organization of the United Nations -FAO. (2016). Increasing the resilience of agricultural livelihoods. Retrieved in 2015, August 2, from http:// www.fao.org/3/a-i5615e.pdf
Garrone, P., Melacini, M., \& Perego, A. (2014). Surplus food recovery and donation in Italy: the upstream process. British Food Journal, 116(9), 1460-1477. http://dx.doi. org/10.1108/BFJ-02-2014-0076.

Ghosh, P. R., Fawcett, D., Sharma, S. B., \& Poinern, G. E. J. (2016). Progress towards sustainable utilisation and management of food wastes in the global economy. International Journal of Food Sciences, 2016, 1-22. http:// dx.doi.org/10.1155/2016/3563478. PMid:27847805.

Girotto, F., Alibardi, L., \& Cossu, R. (2015). Food waste generation and industrial uses: a review. Waste Management (New York, N.Y.), 45, 32-41. http://dx.doi. org/10.1016/j.wasman.2015.06.008. PMid:26130171.

Giuseppe, A., Mario, E., \& Cinzia, M. (2014). Economic benefits from food recovery at the retail stage: an application to Italian food chains. Waste Management (New York, N.Y.), 34(7), 1306-1316. http://dx.doi. org/10.1016/j.wasman.2014.02.018. PMid:24685399.

Göbel, C., Langen, N., Blumenthal, A., Teitscheid, P., \& Ritter, G. (2015). Cutting food waste through cooperation along the food supply chain. Sustainability, 7(2), 14291445. http://dx.doi.org/10.3390/su7021429.

Golgeci, I., \& Ponomarov, S. Y. (2013). Does firm innovativeness enable effective responses to supply chain disruptions? An empirical study. Supply Chain Management, 18(6), 604-617. http://dx.doi.org/10.1108/ SCM-10-2012-0331.

Gruber, V., Holweg, C., \& Teller, C. (2016). What a waste! Exploring the human reality of food waste from the store manager's perspective. Journal of Public Policy \& Marketing, 35(1), 3-25. http://dx.doi.org/10.1509/ jppm.14.095.

Gustavsson, J., Cederberg, C., Sonesson, U., Van Otterdijk, R., \& Meybeck, A. (2011). Global food losses and food waste. Rome: FAO. Retrieved in 2015, August 2, from http://www.fao.org/docrep/014/mb060e/mb060e00.pdf

Halloran, A., Clement, J., Kornum, N., Bucatariu, C., \& Magid, J. (2014). Addressing food waste reduction in Denmark. Food Policy, 49, 294-301. http://dx.doi. org/10.1016/j.foodpol.2014.09.005.

Hohenstein, N.-O., Feisel, E., Hartmann, E., \& Giunipero, L. (2015). Research on the phenomenon of supply chain resilience: a systematic review and paths for further investigation. International Journal of Physical Distribution \& Logistics Management, 45(1-2), 90-117. http://dx.doi.org/10.1108/JJPDLM-05-2013-0128.

Holweg, C., Teller, C., \& Kotzab, H. (2016). Unsaleable grocery products, their residual value and instore logistics. International Journal of Physical Distribution \& Logistics Management, 46(6/7), 634-658. http:// dx.doi.org/10.1108/IJPDLM-11-2014-0285.

Ishikawa, K. (1986). TQC-Total Quality Control: estratégia $e$ administração da qualidade. São Paulo: IMC Internacional Sistemas Educativos. 
Jesson, J., Matheson, L., \& Lacey, F. M. (2011). Doing your literature review: traditional and systematic techniques (pp. 103-127). Londres: Sage.

Johnson, N., Elliott, D., \& Drake, P. (2013). Exploring the role of social capital in facilitating supply chain resilience. Supply Chain Management, 18(3), 324-336. http://dx.doi.org/10.1108/SCM-06-2012-0203.

Jüttner, U., \& Maklan, S. (2011). Supply chain resilience in the global financial crisis: an empirical study. Supply Chain Management, 16(4), 246-259. http://dx.doi. org/10.1108/13598541111139062.

Kaipia, R., Dukovska-Popovska, I., \& Loikkanen, L. (2013). Creating sustainable fresh food supply chains through waste reduction. International Journal of Physical Distribution \& Logistics Management, 43(3), 262-276. http://dx.doi.org/10.1108/IJPDLM-11-2011-0200.

Kamalahmadi, M., \& Parast, M. M. (2016). A review of the literature on the principles of enterprise and supply chain resilience: major findings and directions for future research. International Journal of Production Economics, 171, 116-133. http://dx.doi.org/10.1016/j. ijpe.2015.10.023.

Kamalahmadi, M., \& Parast, M. M. (2017). An assessment of supply chain disruption mitigation strategies. International Journal of Production Economics, 184, 210-230. http://dx.doi.org/10.1016/j.ijpe.2016.12.011.

Khan, O., Christopher, M., \& Creazza, A. (2012). Aligning product design with the supply chain: a case study. Supply Chain Management, 17(3), 323-336. http:// dx.doi.org/10.1108/13598541211227144.

Krippendorff, K. (2013). Content analysis: an introduction to its methodology (3rd ed.). Los Angeles: Sage Publications.

Kume, H. (1993). Métodos estatísticos para melhoria da qualidade. São Paulo: Editora Gente.

Lebersorger, S., \& Schneider, F. (2014). Food loss rates at the food retail, influencing factors and reasons as a basis for waste prevention measures. Waste Management (New York, N.Y.), 34(11), 1911-1919. http://dx.doi. org/10.1016/j.wasman.2014.06.013. PMid:25060676.

Macfadyen, S., Tylianakis, J. M., Letourneau, D. K., Benton, T. G., Tittonell, P., Perring, M. P., Gómez-Creutzberg, C., Báldi, A., Holland, J. M., Broadhurst, L., Okabe, K., Renwick, A. R., Gemmill-Herren, B., \& Smith, H. G. (2015). The role of food retailers in improving resilience in global food supply. Global Food Security, 7, 1-8. http://dx.doi.org/10.1016/j.gfs.2016.01.001.

Manning, L., \& Soon, J. M. (2016). Building strategic resilience in the food supply chains. British Food Journal, 118(6), 1477-1493. http://dx.doi.org/10.1108/ BFJ-10-2015-0350.

Mena, C., Adenso-Diaz, B., \& Yurt, O. (2011). The causes of food waste in the supplier-retailer interface: evidences from the UK and Spain. Resources, Conservation and Recycling, 55(6), 648-658. http://dx.doi.org/10.1016/j. resconrec.2010.09.006.
Mena, C., Terry, L. A., Williams, A., \& Ellram, L. (2014). Causes of waste across multi-tier supply networks: cases in the UK food sector. International Journal of Production Economics, 152, 144-158. http://dx.doi. org/10.1016/j.ijpe.2014.03.012.

Papadopoulos, T., Gunasekaran, A., Dubey, R., Altay, N., Childe, S. J., \& Fosso-Wamba, S. (2017). The role of Big Data in explaining disaster resilience in supply chains for sustainability. Journal of Cleaner Production, 142, 1108-1118. http://dx.doi.org/10.1016/j. jclepro.2016.03.059.

Papargyropoulou, E., Lozano, R., K. Steinberger, J., Wright, N., \& Ujang, Z. (2014). The food waste hierarchy as a framework for the management of food surplus and food waste. Journal of Cleaner Production, 76, 106115. http://dx.doi.org/10.1016/j.jclepro.2014.04.020.

Parfitt, J., Barthel, M., \& Macnaughton, S. (2010). Food waste within food supply chains: quantification and potential for change to 2050. Philosophical Transactions of the Royal Society of London. Series B, Biological Sciences, 365(1554), 3065-3081. http://dx.doi.org/10.1098/ rstb.2010.0126. PMid:20713403.

Pereira, C. R., Christopher, M., \& Silva, A. L. (2014). Achieving supply chain resilience: the role of procurement. Supply Chain Management, 19(5-6), 626-642. http:// dx.doi.org/10.1108/SCM-09-2013-0346.

Pettit, T. J., Croxton, K. L., \& Fiksel, J. (2013). Ensuring supply chain resilience: development and implementation of an assessment tool. Journal of Business Logistics, 34(1), 46-76. http://dx.doi.org/10.1111/jbl.12009.

Pettit, T. J., Fiksel, J., \& Croxton, K. L. (2010). Ensuring supply chain resilience: development of a conceptual framework. Journal of Business Logistics, 31(1), 1-22. http://dx.doi.org/10.1002/j.2158-1592.2010.tb00125.x.

Priefer, C., Jörissen, J., \& Bräutigam, K. R. (2016). Food waste prevention in Europe - A cause-driven approach to identify the most relevant leverage points for action. Resources, Conservation and Recycling, 109, 155-165. http://dx.doi.org/10.1016/j.resconrec.2016.03.004.

Provalis Research. (2017). Introducing QDA Miner: qualitative text analysis software. Retrieved in 2017, December 15, from https://provalisresearch.com/ products/qualitative-data-analysis-software

Raak, N., Symmank, C., Zahn, S., Aschemann-Witzel, J., \& Rohm, H. (2017). Processing-and product-related causes for food waste and implications for the food supply chain. Waste Management, 61, 461-472. http:// dx.doi.org/10.1016/j.wasman.2016.12.027.

Rajesh, R., \& Ravi, V. (2015). Modeling enablers of supply chain risk mitigation in electronic supply chains: a GreyDEMATEL approach. Computers \& Industrial Engineering, 87, 126-139. http://dx.doi.org/10.1016/j.cie.2015.04.028.

Richter, B., \& Bokelmann, W. (2016). Approaches of the German food industry for addressing the issue of food losses. Waste Management (New York, N.Y.), 48, 423 - 
429. http://dx.doi.org/10.1016/j.wasman.2015.11.039. PMid:26691601.

Sahu, A. K., Datta, S., \& Mahapatra, S. S. (2017). Evaluation of performance index in resilient supply chain: a fuzzybased approach. Benchmarking, 24(1), 118-142. http:// dx.doi.org/10.1108/BIJ-07-2015-0068.

Scholten, K., Scott, P. S., \& Fynes, B. (2014). Mitigation processes - antecedents for building supply chain resilience. Supply Chain Management, 19(2), 211-228. http://dx.doi.org/10.1108/SCM-06-2013-0191.

Shafiee-Jood, M., \& Cai, X. (2016). Reducing food loss and waste to enhance food security and environmental sustainability. Environmental Science \& Technology, 50(16), 8432-8443. http://dx.doi.org/10.1021/acs. est.6b01993. PMid:27428555.

Silvestre, B. S. (2015). Sustainable supply chain management in emerging economies: environmental turbulence, institutional voids and sustainability trajectories. International Journal of Production Economics, 167, 156-169. http://dx.doi.org/10.1016/j.ijpe.2015.05.025.

Soni, U., Jain, V., \& Kumar, S. (2014). Measuring supply chain resilience using a deterministic modeling approach. Computers \& Industrial Engineering, 74(1), 11-25. http://dx.doi.org/10.1016/j.cie.2014.04.019.

Stecke, K. E., \& Kumar, S. (2009). Sources of supply chain disruptions, factors that breed vulnerability, and mitigating strategies. Journal of Marketing Channels, 16(3), 193226. http://dx.doi.org/10.1080/10466690902932551.

Svensson, G. (2003). The principle of balance between companies' inventories and disturbances. Empirical illustration and conceptualization. International Journal of Physical Distribution \& Logistics Management, 33(9), 765-784. http://dx.doi.org/10.1108/09600030310503325.

Thyberg, K. L., \& Tonjes, D. J. (2016). Drivers of food waste and their implications for sustainable policy development. Resources, Conservation and Recycling, 106, 110-123. http://dx.doi.org/10.1016/j.resconrec.2015.11.016.

Tostivint, C., de Veron, S., Jan, O., Lanctuit, H., Hutton, Z. V., \& Loubière, M. (2017). Measuring food waste in a dairy supply chain in Pakistan. Journal of Cleaner
Production, 145, 221-231. http://dx.doi.org/10.1016/j. jclepro.2016.12.081.

Tromp, S. O., Haijema, R., Rijgersberg, H., \& van der Vorst, J. G. (2016). A systematic approach to preventing chilled-food waste at the retail outlet. International Journal of Production Economics, 182, 508-518. http:// dx.doi.org/10.1016/j.ijpe.2016.10.003.

Tukamuhabwa, B. R., Stevenson, M., Busby, J., Zorzini, M., \& Bell, M. Z. (2015). Supply chain resilience: definition, review and theoretical foundations for further study. International Journal of Production Research, 53(18), 5592-5623. http://dx.doi.org/10.1080/002075 43.2015.1037934.

Warshawsky, D. N. (2015). Food waste, sustainability, and the corporate sector: case study of a US food company. The Geographical Journal, 182(4), 384-394. http:// dx.doi.org/10.1111/geoj.12156.

Wieland, A., \& Wallenburg, C. M. (2013). The influence of relational competencies on supply chain resilience: a relational view. International Journal of Physical Distribution \& Logistics Management, 43(4), 300-320. http://dx.doi.org/10.1108/IJPDLM-08-2012-0243.

Willersinn, C., Mack, G., Mouron, P., Keiser, A., \& Siegrist, M. (2015). Quantity and quality of food losses along the Swiss potato supply chain: stepwise investigation and the influence of quality standards on losses. Waste Management (New York, N.Y.), 46, 120 132. http://dx.doi.org/10.1016/j.wasman.2015.08.033. PMid:26341828.

Zhang, D., Dadkhah, P., \& Ekwall, D. (2011). How robustness and resilience support security business against antagonistic threats in transport network. Journal of Transportation Security, 4(3), 201-219. http://dx.doi. org/10.1007/s12198-011-0067-2.

Zhang, Y., Zou, D., Zheng, J., Fang, X., \& Luo, H. (2016). Formation mechanism of quick emergency response capability for urban rail transit: inter-organizational collaboration perspective. Advances in Mechanical Engineering, 8(6), 1687814016647881. http://dx.doi. org/10.1177/1687814016647881. 